\title{
Evaluation of Aflatoxin M1 Residues in Traditional Iranian Cheese (Koupeh Cheese) samples by ELISA
}

\author{
Awat Ebrahim (MSc) \\ Department of Food Science and \\ Technology, Islamic Azad University, \\ Tabriz Branch, Tabriz, Iran \\ Keiwan Ebrahimi Mohammadi \\ (PhD) \\ Department of Food Science and \\ Technology, Faculty of Agriculture, \\ Islamic Azad University, Mahabad \\ Branch, Mahabad, Iran \\ Corresponding author: Keiwan \\ Ebrahimi Mohammadi \\ Email: keiwan1976@yahoo.com \\ Tel: +989363679725 \\ Address: Department of Food Science \\ and Technology, Faculty of \\ Agriculture, Islamic Azad University, \\ Mahabad Branch, Mahabad, Iran \\ Received : 24 Feb 2018 \\ Revised: 01 Apr 2018 \\ Accepted: 16 Apr 2018 \\ Awat Ebrahim https://orcid.org/0000-0001-8377- \\ 5095 \\ Keiwan Ebrahimi Mohammadi \\ https://orcid.org/0000-0001-7241-0154
}

\section{ABSTRACT}

Background and Objectives: Local cheese made from raw milk is one of the most commonly consumed dairy products in the world. Mycotoxin contamination of foodstuff and its transmission to consumers are extremely important public health issues. The purpose of this survey was to determine the level of aflatoxin MI (AFMI) residues in Koupeh cheese, a traditional fermented Iranian cheese produced in spring and summer.

Methods: We randomly collected 40 local cheese samples produced in Mahabad (northwest of Iran) during spring and summer. The level of AFMl was measured by enzymelinked immunosorbant assay using commercial kits and a microplate reader.

Results: All samples contained measurable amounts of AFMl. Cow milk cheese samples contained higher level of AFMl compared to sheep milk cheese samples. The level of AFMl in the samples from both animals was lower in summer. There was no significant difference between the mean level of AFII in summer and spring. Moreover, 33.3\% of cow milk cheese samples collected in spring and $16.6 \%$ of the samples collected in summer contained toxin levels higher than the maximum allowed concentration set by the European Commission $(250 \mathrm{ng} / \mathrm{Kg}$ ) and by the Institute of Standards and Industrial Research of Iran $(200 \mathrm{ng} / \mathrm{Kg})$.

Conclusion: The results of this study show that the level of AFMlin Koupeh cheese is influenced by the livestock type and production season, in a way that the level of contamination is higher in spring.

Keywords: Cheese, Cultured Milk Products, Aflatoxin Ml, ELISA. 


\section{INTRODUCTION}

Milk and dairy products are main parts of human diet. A close relationship has been reported between consumption of dairy products and health status, efficiency, IQ, and the regulation of metabolic activities (1). The quality of milk and dairy products is important and relies mainly on the health of livestock and their feed (2). Various studies on animal feed have shown that the contamination of animal feed with molds (especially Aspergillus species) leads to production and transfer of aflatoxin to milk and its products $(1,2)$. Livestock can be exposed to mycotoxins such as aflatoxin through consumption of the feeds contaminated with mycotoxin-producing molds during growth, harvest, and storage. When lactating animals such as cattle consume aflatoxin B1 (AFB1)-contaminated feed, the toxin is metabolized to form the monohydroxy derivative, aflatoxin M1 (AFM1), which is excreted in their milk (3). The presence of mycotoxins in food and animal feed depends on various factors such as geographical area, season, humidity, temperature, and storage conditions. The presence of AFM1 in milk and dairy products can cause toxicity and carcinogenicity. Aflatoxins are as large group of mycotoxins produced by Aspergillus species such as Aspergillus flavus, Aspergillus parasiticus and Aspergillus nomius (4, 5). AFM1 is the hydroxylated metabolite of AFB1 (6) excreted in milk through mammary glands of human and lactating animals (7). About 0.3$6.2 \%$ of AFB1 is metabolized into AFM1 and then excreted in milk depending on factors including animal genetics, seasonal variation, milking process, and environmental conditions (8). The nutritional value of dairy products is strongly influenced by the quality of raw milk. In Iran, cheese production has become popular in the recent years and according to statistics, about $20 \%$ of milk produced in the country is converted to cheese in the dairy industry. Moreover, the share of traditional cheese production is about $80 \%$ (9). The International Agency for Research on Cancer (IARC) has identified AFB1 as a carcinogen (10). Studies have shown that the presence of AFM1 in milk and dairy products is health threatening, especially in the populations where dairy products are the main part of the daily diet (7). Therefore, in this study, we determined the level of AFM1 residues in Koupeh cheese, a traditional fermented Iranian cheese produced in spring and summer.

\section{MATERIAL AND METHODS}

This observational and cross sectional study was performed on 48 randomly collected traditional cheese samples from the city of Mahabad (Iran) during spring and summer. The samples (100g each) were kept in freezer at $-18{ }^{\circ} \mathrm{C}$. Presence of AFM1 in the samples was evaluated by enzyme-linked immunosorbent assay (ELISA). ELISA kits (sensitivity of $5 \mathrm{ng} / \mathrm{L}$ ) used in this study were purchased from R-Biopharm Inc., Germany. In this test, cross-reaction with AFM1 was 100\% and no cross-reactivity was observed with AFB1, B2, G1 and G2. Moreover, the aflatoxin recycling rate has been reported to be 95\% with $15 \%$ error rate. First, the samples were thawed and placed in the bottom of a refrigerator for 12 hours before the test. After homogenization, $2 \mathrm{~g}$ of each cheese sample were weighed accurately and then added to a $50 \mathrm{ml}$ balloon containing $40 \mathrm{ml}$ of dichloromethane. The contents were stirred for 15 minutes and the suspension was filtered using syringe filters. Then, $10 \mathrm{ml}$ of the filtrate was evaporated at $60{ }^{\circ} \mathrm{C}$ and the sediment was dissolved in a mixture of $0.5 \mathrm{ml}$ methanol with $0.5 \mathrm{ml}$ phosphate buffer and $1 \mathrm{ml}$ heptane. The mixture was centrifuged at 2700 RPM for 15 minutes at $10^{\circ \mathrm{C}}$. Supernatant (heptane layer) was removed completely and $100 \mu 1$ of subphase (methanol layer) was diluted with $400 \mu \mathrm{l}$ of phosphate buffer. Later, $100 \mu \mathrm{l}$ of standard solution and the prepared cheese samples were added to a microplate. After placing the microplate at $20-25{ }^{\circ} \mathrm{C}$ for an hour, the content of the microplate was removed and all wells were washed with $250 \mu \mathrm{l}$ of special wash buffer. Next, $100 \mu$ of aflatoxin solution conjugated to the enzymes was added to the wells and the microplate was placed in an oven at $25-20{ }^{\circ} \mathrm{C}$ for an hour. The contents of the wells were removed completely and the wells were washed twice with $250 \mu \mathrm{l}$ of the wash buffer. Then, $50 \mu \mathrm{l}$ of substrate and $50 \mu \mathrm{l}$ of chromogen were added to each well and the microplate was incubated in the dark at 20-25 ${ }^{\circ} \mathrm{C}$ for 30 minutes. Finally, the reaction was inhibited by adding $100 \mu \mathrm{l}$ of stop solution. Absorbance of each sample at $450 \mathrm{~nm}$ was read with BioTek ELISA Reader (USA). The 
results were analyzed using SAS (version 9.1) and Microsoft Excel 2007.

\section{RESULTS}

The results showed that all samples contained measurable amounts of AFM1. The cheese produced from cow's milk had higher concentrations of AFM1 compared to the cheese produced from sheep's milk (Table 1). The level of AFM1 contamination in both animal species was higher in the spring. The highest concentration of AFM1 was detected in the cheese produced from cow's milk in the spring. However, the lowest amount of AFM1 was found in the sheep milk cheese produced in the summer $(45.86 \mathrm{ng} / \mathrm{Kg})$. However, the lowest mean level of AFM1 was related to the cow milk cheese produced in the summer.There was no statistically significant difference between the mean level of aflatoxin found in cow and sheep milk cheese $(\mathrm{P}>0.05)$. The results also showed that the mean concentration of aflatoxin in spring and summer was significantly different $(\mathrm{P}<0.05)$.

The highest mean level of AFM1 was found in the samples collected in the spring (186.66 $\mathrm{ng} / \mathrm{Kg}$ ), while the lowest mean AFM1 level was related to the samples collected in the summer (136.06 ng/Kg) (Figure 1). We also found that the highest level of AFM1 in the cheese samples from both animals was related to the spring, indicating that season might be a determining factor for the level of aflatoxin contamination of dairy products (Figure 1).

Table 1- Mean level and range of AFM1 contamination in cheese samples produced from cow and sheep milk

\begin{tabular}{|c|c|c|c|c|}
\hline \multirow[t]{2}{*}{ Livestock } & \multirow[t]{2}{*}{ Season } & \multirow{2}{*}{$\begin{array}{l}\text { Number of } \\
\text { samples }\end{array}$} & \multicolumn{2}{|c|}{ Concentration of AFM1 (ng/Kg) } \\
\hline & & & Range (ng/Kg) & $\begin{array}{c}\text { Mean } \pm \text { Standard } \\
\text { deviation }\end{array}$ \\
\hline \multirow[t]{2}{*}{ Cow } & Spring & 12 & 92.3-348.3 & $198.24 \pm 91.55$ \\
\hline & Summer & 12 & $51.9-280.1$ & $134.75 \pm 69.2$ \\
\hline \multirow[t]{3}{*}{ Sheep } & Spring & 12 & 70.1-382.3 & $175.07 \pm 86.33$ \\
\hline & Summer & 12 & $45.86-264.3$ & $137.3 \pm 61.7$ \\
\hline & & 48 & & \\
\hline
\end{tabular}

Table 2-AFM1 level in traditional cheese samples depending on the season and type of animal

\begin{tabular}{cccccc}
\hline Livestock type & Seasons & $\begin{array}{c}\text { Number of } \\
\text { samples }\end{array}$ & Range $(\mathrm{ng} / \mathrm{Kg})$ & \multicolumn{2}{c}{$\begin{array}{c}\text { Higher than the European } \\
\text { standard }(\mathbf{2 5 0} \mathrm{ng} / \mathrm{Kg})\end{array}$} \\
\cline { 3 - 5 } & & & & $\begin{array}{c}\text { Number of } \\
\text { samples }\end{array}$ & $\%$ \\
Cow & Spring & 12 & $\mathbf{9 2 . 3 - 3 4 8 . 3}$ & 4 & 33.33 \\
Sheep & Spring & 12 & $\mathbf{7 0 . 1 - 3 8 2 . 3}$ & 2 & 16.6 \\
Cow & $\begin{array}{c}\text { Summer } \\
\text { Sheep }\end{array}$ & 12 & $\mathbf{5 1 . 9 - 2 8 0 . 1}$ & 1 & 8.33 \\
\hline
\end{tabular}

Table 2 represents the results of the statistical analysis of AFM1 levels in the samples based on the season and type of animal.

Figure 1- Comparison of the mean concentration of AFM1 in cheese produced from cow and sheep milk in different seasons

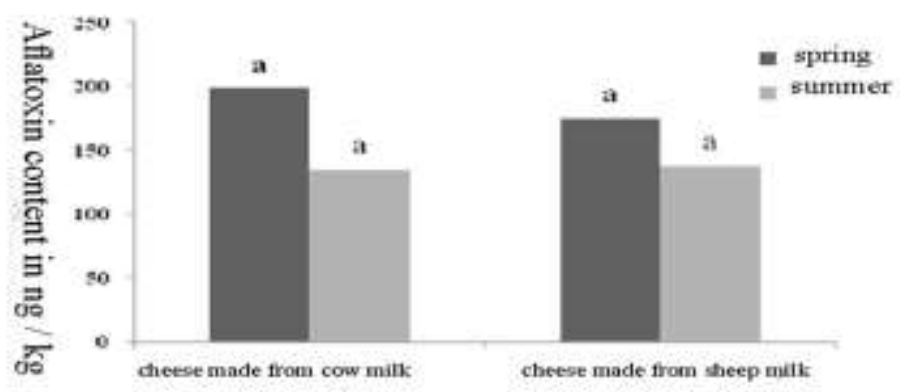




\section{DISCUSSION}

Several studies have been conducted about the presence and level of aflatoxin in milk and dairy products. The results of such studies indicate that the prevalence and concentration of contamination is high and risky in some cases but lower than the maximum allowed limit in some other cases. In a study carried out by Falah et al. on 116 white cheese and 94 raw cheese samples, aflatoxin was detected in 161 samples with contamination range of $52.1-785.4 \mathrm{ng} / \mathrm{Kg}$, while contamination level in $24.24 \%$ of the samples was higher than the maximum allowed limit set by the European Commission regulation $(250 \mathrm{ng} / \mathrm{Kg})$ (7). It should be noted that the maximum allowed limit for presence of AFM1 in cheese has been set at $200 \mathrm{ng} / \mathrm{Kg}$ by the Institute of Standards and Industrial Research of Iran (11). In another study conducted by Tickson in Turkey, the amount of aflatoxin in 92 butter and 100 raw cheese samples was studied with ELISA and the results showed that all butter samples and $99 \%$ of the cheese samples were contaminated with the toxin. In addition, the level of aflatoxin in $28 \%$ of butter samples and $18 \%$ of cheese samples was higher than the allowed limit set by the Turkish Food Codex (250 ng/Kg) (12). In a study by Mokhtarian and Mohsenzadeh in Gonabad (Iran), it was found that $58 \%$ of milk samples contained aflatoxin concentrations higher than the standard limit (13). In Turkey, Yarglio et al. evaluated aflatoxin levels in 600 white cheese samples using ELISA. The mentioned study reported that $5 \%$ of the samples contained $100-800 \mathrm{ng} / \mathrm{Kg}$ aflatoxins and $1 \%$ of the samples were contaminated with aflatoxin concentrations higher than the allowed limit set by the Turkish Food Codex (14). In a study by Neisi et al., concentration of AFB1 in buffalo feed samples ranged from 0.77 to $64.85 \mu \mathrm{g} / \mathrm{Kg}$. In addition, the concentration of aflatoxin in 21 samples was higher than the allowed limit $(25 \mu \mathrm{g} / \mathrm{Kg})(16)$. The incongruity in the results of the studies could be associated with several factors including type of cheese production, level of animal feed contamination, quality of milk used for cheese production, transport and storage conditions, and the methods used for the analysis of aflatoxin content (16). The AFM1 content of milk produced in different areas is also influenced by geographical and seasonal factors. For instance, it has been reported that the level of contamination in summer is significantly lower than that in winter (16). In our study, there was a significant difference between the level of aflatoxin in spring and summer, which might indicate a relationship with livestock feeding. Considering the lake of a significant difference in the amount of AFM1 between the cheese samples produced from milk of different livestock, it can be concluded that the level of aflatoxin in the milk could be associated with the feeding of lactating animals in the study area.

Feed type, cultivation, preservation method, temperature and humidity can exacerbate contamination of milk, but the exact effect or mechanism of action of these factors is not clear (17).

\section{CONCLUSION}

Based on the results of our study and previous studies in Iran, it should be noted that the level of contamination of local cheese with AFM1 is undesirable. Lack of timely and effective measures for control of aflatoxin contamination in dairy products could lead to serious health consequences. Since AFM1 is the result of the animal's metabolism, it is suggested to conduct more accurate studies on the AFB1 contamination of animal feed. Furthermore, in order to reduce the health risks associated with aflatoxin contamination, modifications should be made regarding the maximum allowed limit of aflatoxin in foodstuffs.

\section{ACKNOWLEDGEMENTS}

The authors would like to thank the Islamic Azad University of Tabriz for supporting this study.

\section{CONFLICT OF INTEREST}

The authors have no conflict of interest to declare. 


\section{REFERENCES}

1. Ranjbar S, Noori M, Nazari R. Study of milk Aflatoxin M1 and its relationship with feed fungi flora in Markazi Province. J Cell Tissue. 2010; 1(1): 9-18.

2. Han RW, Zheng N, Wang JQ, Zneh YO, Xu XM, Li SL. Survey of Aflatoxin in dairy cow feed and raw milk in China. J Food Control. 2013; 34(1): 35-39.

3. Helena Iha M, Baltazar Barbosa C, Akemi Okada I, Truckess MW. Aflatoxin M1 in milk and distribution and stability of aflatoxin M1 during production ans storage of yoghurt and cheese. J Food Control. 2013; 29: 1-6.

4. Creppy EE. Update of survey, regulation and toxic effects of mycotoxins in Europe. Toxicol Lett. 2002; 127(1-3): 19-28.

5. Memari H, Ebrahimi Mohammadi K, Esmaeilzadeh P. "Total Aflatoxin", "Aflatoxin B1" And "Ochratoxin A" Residues In Wheat Flour Produced In Kurdistan Province-Iran. Medical Laboratory Journal. 2017; 11(5): 1-6.

6. Asi MR, Iqbal SZ, Arino A, Hussain A. Effect of seasonal variations and lactation times on Aflatoxin M1 contamination in milk of different species from Punjab, Pakistan. J Food Control. 2002; 25(1): 34-38.

7. Fallah AA, Jafari T, Rahnama M. Determination of aflatoxin M1 levels in Iranian white and cream cheese. $\mathrm{J}$ Food and Chemical Toxicology. 2009; 47(8): 1872-1875. 8. Unusan N. Occurrence of aflatoxin M1 in UHT milk in Turkey. J Food and Chemical Toxicology. 2006; 44(11): 1897-1900.

9. Arenas R, Gonzalez L, Bernardo A, Fresno JM, Tornadijo ME. Microbiological and physico-chemical changes in Genestoso cheese, a Spanish acid curd variety, throughout ripening. J Food Control. 2004; 15(4): 271-279.
10. IARC. IARC monographs on the evaluation of carcinogenic risks to humans. In Traditional herbal medicines, some Mycotoxins, Napthalene and styrene (Vol. 82). Lyon: IARC Press. 2002.

11. Mahmoudi R., Golchin A., Hosseinzadeh N., Ghajarbeygi P. Aflatoxin $\mathrm{M} 1$ and B1 contaminations in products of animal origin in Iran. J Qazvin University Medicine Sciences (JQUMS). 2014; 18(4): 49-59.

12. Tekinsen K, Ucar G. Aflatoxin M1 levels in butter and cream cheese consumed in Turkey. J Food Control. 2008; 19(1): 27-30.

13. Mokhtarian-Dalooee H, Mohsenzadeh H. Evaluation of aflatoxin M1 in pasteurized milk in Gonabad city. Ofogh-e- Danesh. 2005; 11(3): 3-9.

14. Yaroglu T, Oruc HH, Tayar M. Aflatoxin M1 levels in cheese samples from some provinces of Turkey. J Food Control. 2005; 16(10): 883-889.

15. Neisi AK, Gharibi H, Takdastan A, Rezazadeh H, Badiee M, Zohrehvand F, et al. Detection of Aflatoxin B1 in Buffalo Feed Samples from Cities of Ahvaz and Karun. Medical Laboratory Journal. 2017; 11(2): 21-25. DOI: 10.18869/acadpub.mlj.11.2.21.

16. Galvano F, Galofaro V, Galvano G. Occurrence and stability of aflatoxin $\mathrm{MI}$ in milk and milk products: A worldwide review. J Food Protection. 1996; 10: 1079-90.

17.Tajkarimi M, Shojaee Aliabadi F, Salah Nejad M, Pursoltani H, Motallebi AA, Mahdavi H. Seasonal study of aflatoxin M1 contamination in milk in five regions in Iran. Int J Food Microbiol. 2007; 116(3): 346-9. 